\title{
Pengembangan Rancangan Media Pembelajaran Augmented Reality Perangkat Jaringan Komputer
}

\author{
Melsi Sari Murfi ${ }^{1,2^{*}}$ dan Kasman Rukun ${ }^{2}$ \\ ${ }^{1}$ SMKN 1 Enam Lingkung Kabupaten Padang Pariaman Sumatera Barat \\ 1,2Prodi Magister Pendidikan Teknologi dan Kejuruan, Fakultas Teknik, Universitas Negeri Padang \\ ${ }^{*}$ Corresponding author, e-mail: murfimelsi@gmail.com
}

\begin{abstract}
Abstrak - Perkembangan teknologi berpengaruh pada aspek pendidikan yang berdampak pada kegiatan pembelajaran. Pada pembelajaran jaringan komputer masih sedikitnya pemanfaatan media yang berdampak pada pemahaman siswa terhadap materi perangkat jaringan komputer. Penelitian ini membahas pengembangan perancangan media pembelajaran Augmented reality perangkat jaringan komputer. Penelitian yang bertujuan untuk mengembangkan media pembelajaran augmented reality dan menghasilkan media yang memudahkan guru siswa dalam memahami pengenalan perangkat jaringan komputer sehingga menjadi alternatif sebagai media pembelajaran. Metode yang digunakan adalah Research and Development (R\&D) dengan menggunakan model IDI, dan selanjutnya dikembangkan menggunakan tools Software Unity dan Vuforia SDK. Hasil penelitian pengembangan media pembelajaran augmented reality dinyatakan valid, praktis dan efektif untuk digunakan sebagai media pembelajaran pada pengenalan perangkat jaringan komputer.
\end{abstract}

Kata Kunci : Media Pembelajaran, Augmented Reality, Vuforia, Jaringan komputer

\begin{abstract}
The developments of technology on educational aspects that have an impact on learning activities. In computer network learning, there is still minimal use of media that impacts students' understanding of computer network devices. The research discusses about development of design augmented reality learning media on computer network devices. This study aims to develop learning media augmented reality and produce media that arevalid, practical, and effective on introduc of computer network devices so that they become alternatives as instructional learning. The method used research and development $(R \& D)$ with IDI model, and then developed using software Unity and Vuforia SDK tool. Result of this research indicate that the development of design augmented reality learning media can be valid, practical and effective to be used as a learning media on introduce of computer network devices.
\end{abstract}

Keywords : Learning Media, Augmented Reality, Vuforia, Computer network

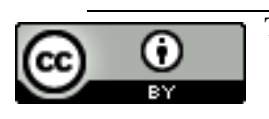

This is an open access article distributed under the Creative Commons 4

\section{Pendahuluan}

Revolusi teknologi berkembang semakin cepat membawa perubahan, dan sekarang di era revolusi industry (R.I) 4.0 memberikan perubahan dalam semua aspek kehidupan[1]. Revolusi industri 4.0 hampir di semua bidang telah berangsurnya perpindahan ke digitalisasi komputer dan automasi. Perubahan ini memerlukan kesiapan menghadapai di masa depan. Tantangan dan peluang revolusi industri 4.0 juga berdampak pada aspek pendidikan termasuk pendidikan kejuruan yang dituntut untuk lebih berinovasi serta diimbangi dengan empat keterampilan abad 21 yakninya keterampilan kreatifitas, berfikir kritis, komunikasi dan kolaborasi.

Perkembangan R. I 4.0 yang sangat beragam, dan berdampak pada perubahan sistem pendidikan Indonesia, dunia pendidikan diharapkan mampu berinovasi dan bersaing dengan perubahan yang ada.Perubahan ini juga berdampak kepada guru yang dituntut untuk sangat efektif dalam mendidik siswa dalam mempersiapkan dan memenuhi kebutuhan R.I 4.0. di pendidikan Penggunaan teknologi dan automasi salah satunya memanfaatkan media pembelajaran berbasis teknologi dalam kegiatan pembelajaran sehingga kebutuhan media tidak ketinggalan dengan 
perkembangan teknologi, dan kegiatan pembelajaran berlangsung tanpa menghambat ruang dan batas waktu dalam memanfaatkan teknologi.

Teknologi yang paling dekat sekarang ini adalah teknologi perangkat gawai smartphone. Smartphone merupakan perangkat seluler yang memiliki fungsi dan kemampuannya menyamai dengan sistem operasi komputer, layaknya komputer dalam genggaman, serta dapat mengimplementasikan berbagai bentuk pekerjaan multimedia. jika melihat penggunaan smartphone di Indonesia, dari tahun 2018 Indonesia menjadi Negara urutan ke-4 di dunia dengan melebihi 100juta pengguna aktif [2].

Dalam kegiatan pembelajaran guru seharusnya bisa memperhatikan pemanfaatan media, dikarenakan itu penggunaan media dalam penyampaikan materi juga harus lebih kreatif dan berinovasi, serta menjadikan kegiatan pembelajaran lebih menyenangkan sehingga termotivasinya siswa[3]. Media pembelajaran merupakan sarana fisik, komunikasi digunakan dalam keperluan pembelajaran untuk membawa pesan yang bisa menyampaikan materi pembelajaran termasuk teknologi [4-6]. Media pembelajaran ada beberapa jenis seperti media cetak, display, media audio, motion picture, media berbasis web, dan multimedia [7, 8].

Jaringan Komputer merupakan salah satu kegiatan pembelajaran pada Sekolah Menengah Kejuruan, pembelajaran ini bertujuan untuk mengembangkan kemampuan siswa dalam menginstalasi jaringan komputer. Metode pengajaran memiliki peranan penting dalam memotivasi siswa mencapat tujuan pembelajaran dan meningkatkan hasil belajar siwa [9]. Kegiatan pembelajaran di sekolah masih sedikit menggunakan media saat jika membutuhkan media pembelajaran hanya aplikasi Microsoft powerpoint yang digunakan sebagai media dalam upaya pemanfaatan teknologi, selain itu metode ceramah masih digunakan dalam penyampaian materi. Namun media pembelajaran memanfaatkan smartphone masih jarang digunakan sebagai media pendukung pembelajaran siswa. Multimedia pembelajaran yang memanfaatkan penggunaan teknologi dapat menjadi media pendukung dalam meningkatkan pembelajaran.

Hasil observasi terdapat beberapa kendala dalam kegiatan pembelajaran, seperti sumber daya alat dan bahan yang terbatas karena beberapa produk yang mahal mengakibatkan pembelajaran tentang pengenalan perangkat jaringan sebatas menjelaskan dan memperkenalkan perangkat yang ada saja tanpa melihat secara keseluruhan. Selain itu, metode pembelajaran ceramah juga membuat siswa kurang termotivasi, menjadikan sedikitnya umpan balik siswa dalam menikmati pembelajaran, ini diperkuat dengan beberapa temuan peneliti yang menyatakan pencapaian nilai pada aspek pengetahuan tergolong rendah, jika dipresentasekan hanya $35 \%$ yang tuntas sedangkan $65 \%$ siswa dikategori belum tuntas dalam menguasai pengetahuan konsep jaringan komputer. Kondisi seperti ini mengharuskan guru untuk lebih berinovasi dalam penyampaian materi ajar, serta kreatif dalam membuat media pembelajaran, supaya mendapatkan motivasi siswa dan tertarik pada kegiatan pembelajaran sehingga meningkatnya pemahaman siswa terhadap materi ajar.

Terdapat berbagai jenis media pembelajaran, diantaranya media pembelajaran berbantu komputer seperti penggunaan aplikasi Microsoft power point sebagai media presentasi, aplikasi mobile learning berbasis android dan berbasis website atau e-learning. Beberapa jenis media terdapat kebaruan suatu media pembelajaran dengan memvisualisasikan yang abstrak menjadi konkret melalui augmented reality. Hendaknya media yang dikembangkan menyusun materi pengajaran dengan unsur-unsur visual dehiingga daya imajinasi siswa meningkat. [10].

Terlihat pada penelitian relevan semakin banyak keberhasilan peneliti pengembangan memanfaatkan media augmented reality sebagai media pembelajaran[11, 12]. Selain itu guru juga dapat memanfaatkan smartphone sebagai media pembelajaran yang berisikan materi ajar, tampilan 3D untuk menampilkan, dan soal untuk evaluasi $[13,14]$.

Augmented reality berpotensi dalam pengembangan aplikasi interaktif [15]. Di Indonesia kemunculannya dikenal dan mendapatkan respon baik dari pengguna android terlihat dari salah satu game berbasis android menggunakan teknologi augmented reality yaitu pokemon go. Pokemon go merupakan salah satu game di platform android yang rilis tahun 2016 dikembangkan oleh Jhon Hanke CEO Niantic Labs.

Perkembangan smartphone semakin baik dengan fitur kamera yang dimiliki nya, banyak bermunculan developer aplikasi perangkat smartphone, bahkan dewasa ini banyaknya pengembangan aplikasi berbasis android 
menggunakan Vuforia software development kit (SDK). Vuforia merupakan pengembangan software oleh Qualcomm yang berfokus pada computer vision focus image recogniting Vuforia bekerja menggunakan marker.[16]

Aplikasi pengembangan augmented reality diantaranya pada bidang pemasaran, pendidikan, medis, pelatihan industri, permainan hingga pariwisata [17]. Peluang augmented reality di bidang pendidikan sangatlah besar, dengan adanya augmented reality materi ajar yang bersifat abstrak dapat divisualkan menjadi lebih konkret, objek diproyeksikan melalui simulasi 3D sehingga objek terlihat secara realtime oleh siswa. Manfaat lainnya dalam penggunaan augmented reality bisa membantu guru untuk menjelaskan dalam penyampaian materi secara baik dan materi ajar mudah dipahami oleh siswa [18].

Media pembelajaran augmented reality diharapkan menghasilkan media pembelajaran bagi siswa, menjadi solusi dari kebosanan dan ketidakefektifan penyampaian materi sehingga smartphone yang dimilikinya memiliki nilai tambah, dan siswa termotivasi dengan kemenarikannya karena penyajiannya tidak hanya berupa teks saja tetapi juga unsur multimedia tampilan 3D yang divisualisasikan agar lebih mudah memahami materi.

Harapan dari penelitian ini dengan media pembelajaran memberikan informasi mengenai perangkat jaringan. Mengembangkan konsep pembelajaran menggunakan media augmented reality upaya memotivasi siswa dan keaktifan siswa lebih meningkat guna menambah pemahaman materi siswa dan berdampak pada hasil belajar. Membantu peserta didik dalam memilih alternatif media sebagai sumber belajar yang fleksibel dan termotivasi dalam kegiatan pembelajaran. Media pembelajaran augmented reality diharapkan guru lebih terdorong dalam mengembangkan media pembelajaran yang kreatif dan inovatif.

Spesifikasi produk yang dikembangkan diantaranya: Pengembangan media berisikan konten materi perangkat jaringan komputer berupa tampilan 3D, teks, gambar serta konten kuis untuk membantu penilaian dengan menggunakan media ini. Aplikasi berkstensi .apk dapat di install pada smartphone berbasis android. Pengembangan media menggunakan aplikasi unity dan vuforia sdk sebagai perangkat pendukung augmented reality. Objek marker di cetak pada berbahan dasar plastik/PVC. Media ini membutuhkan spesifikasi produk minimal smartphone: Android versi Jelly bean, RAM $1 \mathrm{~GB}$, internal storage $2 \mathrm{~GB}$, CPU 1,2 GHz dan kamera 2MP.

\section{METODA}

Penelitian ini menghasilkan sebuah pengembangan media pembelajaran, Research and development $(\mathrm{R} \& \mathrm{D})$ dipilih sebagai metode dan memilih model pengembangannya IDI, dimana meliputi tahapan define, develop dan evaluate. Mengidentifikasi masalah, analisis kurikulum dan analisis konsep merupakan tahap awal atau tahap define (penentuan). Selanjutnya pada tahap develop (pengembangan) rancangan awal (prototype) produk disusun dan memvalidasikan produk. Diakhiri dengan pengujicobaan produk dan analisis hasil uji coba pada tahap evaluate (penilaian).

Setelah media pembelajaran dinyatakan valid sama validator, maka selanjutnya melakukan pengujian kemudahan/ praktikalitas penggunaan media pembelajaran augmented reality perangkat jaringan komputer, data diperoleh dari guru dan siswa melalui angket. Lembar praktikalitas meliputi persepsi dan saran guru dan siswa terhadap pengembangan media perangkat jaringan komputer. Perolehan skor item dilakukan pentabulasin mencari persentase dengan ketentuan.

Nilai Praktikalitas

$=$

$\frac{\text { jumlah skor jawaban masing-masing item }}{\text { jumlah skor ideal item }} \times 100 \%$

Analisis praktikalitas nilai skor guru dan siswa dikategorikan dengan pengelompokkan [19]:

Tabel 1. Kategori Praktikalitas

\begin{tabular}{|c|c|c|}
\hline No & Tingkat Pencapaian & Kategori \\
\hline 1 & $81-100$ & Sangat Praktis \\
2 & $61-80$ & Praktis \\
3 & $41-60$ & Cukup Praktis \\
4 & $21-40$ & Kurang Praktis \\
5 & $0-20$ & Tidak Praktis \\
\hline
\end{tabular}

Teknik memvaliditas, praktikalitas penggunaan media pembelajaran augmented reality jaringan komputer dibantu dengan menggunakan aplikasi Microsoft office excel sebagai tolls untuk analisa data. Berikut alur dari pengembangan rancangan media pembelajaran, 


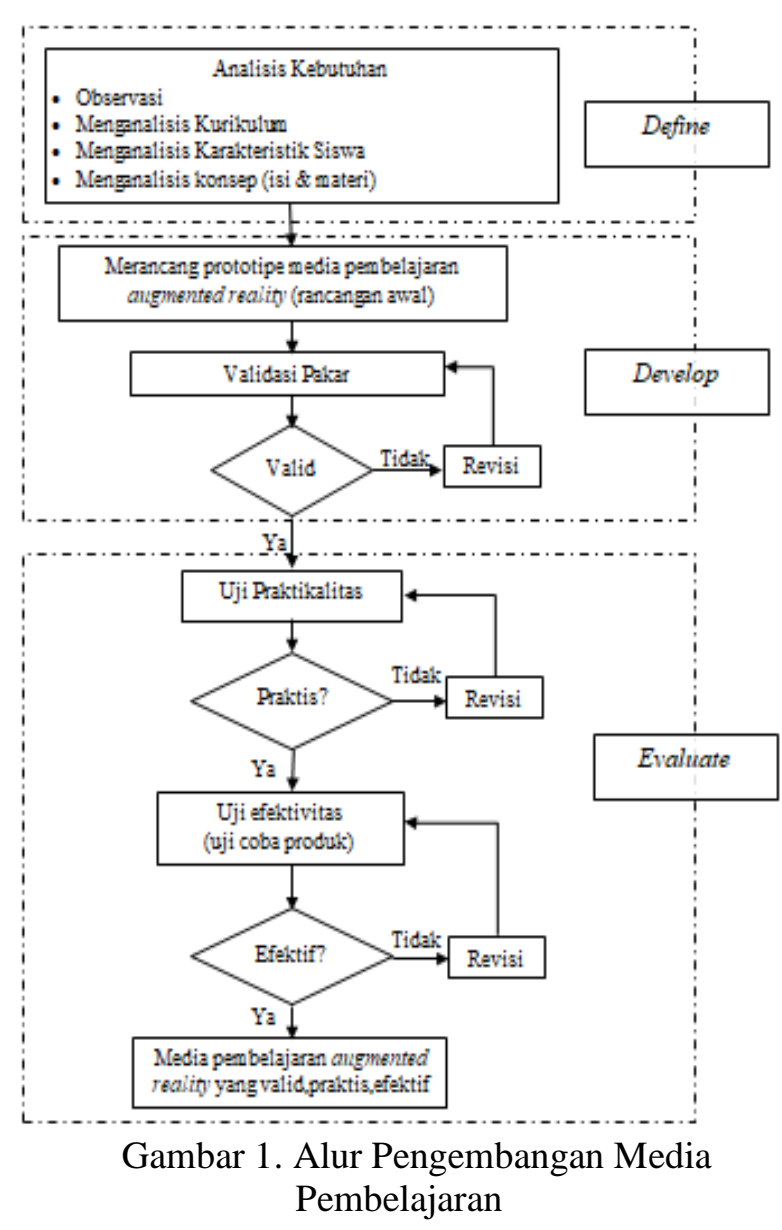

\section{HASIL DAN PEMBAHASAN}

Perancangan media pembelajaran ini diawali mengaanalisis kebutuhan sistem, kemudian dilanjutkan dengan merancang desain interface aplikasi, setelah itu diinterpretasikan dalam pembuatan sistem (coding) media pembelajaran, dan selanjutnya pengujicobaan media kepada siswa dan guru yang akan menggunakan media pembelajaran Augmented reality perangkat jaringan.

Awal dari tahap define melakukan analisis kebutuhan media pembelajaran Augmented Realityyang meliputi menganalisis karakteristik siswa dan konsep dari materi pembelajaran perangkat jaringan komputer. Dari pengamatan, hasil wawancara guru dan siswa, maka dapat disimpulkan bahwa untuk pembelajaran pada mata pelajaran komputer dan jaringan dasar diperlukannya media pembelajaran sebagai sumber belajar siswa. Dirancang dari isi dan desain yang dipertimbangkan. Penyesuaian kurikulum dan silabus pada isi media, sedangkan aspek tampilan memperhitungkan desain media pembelajaran augmented reality yang dikembangkan. Sesudahnya media pembelajaran augmented reality dibuat maka selanjutnya dilakukan tahap validasi terhadap pakar yang bertujuan untuk menentukan layak atau tidaknya media pembelajaran augmented reality tersebut.

\section{Halaman Awal Menu}

Tampilan halaman awal menu terdapat button menu materi yang berisi tentang materi perangkat jaringan komputer didalam menu utama akan terdapat sub menu tentang rincian materi perangkat jaringan.

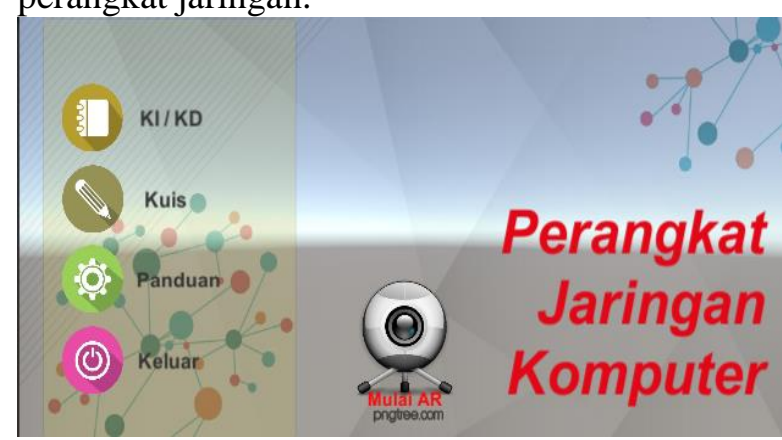

Gambar 2. Tampilan Menu Utama

Halaman awal menu terdapat lima button navigasi. Setiap button akan melakukan perintah sesuai dengan fungsi nya.

a. Button MulaiAR. Berfungsi berpindah ke tampilan scan/deteksi marker.

b. Button KI/KD. Berguna mengalihkan tampilan ke halaman kompetensi dasar materi.

c. Button kuis. Button yang akan berisikan evaluasi materi.

d. Button Panduan. akan menampilkan halaman panduan yang berisikian petunjuk pemakaian aplikasi.

e. Button keluar. Jika ingin keluar dari aplikasi, Button ini fungsinya.

f. Button next. Berguna berpindah halaman ke scane berikutnya.

g. Button back. Button yang berfungsi berpindah ke halaman sebelumnya.

Tampilan button kuis berisi latihan-latihan soal yang dapat mengevaluasi kemampuan peserta didik tentang perangkat jaringan komputer, informasi penggunaan aplikasi augmented reality jaringan komputer dapat dilihat pada button panduan.

\section{Halaman Mulai $A R$}

Halaman Mulai Augmented Reality (AR) merupakan bagian dari aplikasi pengembangan media pembelajaran, dimana halaman ini kamera smartphone akan diaktifkan guna menscan marker 
untuk menampilakn objek 3D perangkat jaringan komputer.

Halaman yang berisikan konten materi dari media pembelajaran augmented reality yang akan dipelajari oleh siswa. Pada halaman ini juga terdapat beberapa tombol berbagai jenis perangkat jaringan komputer. Dengan memilih salah satu tombol jenis perangkat maka pengguna akan dibawa ke halaman menu scan marker.

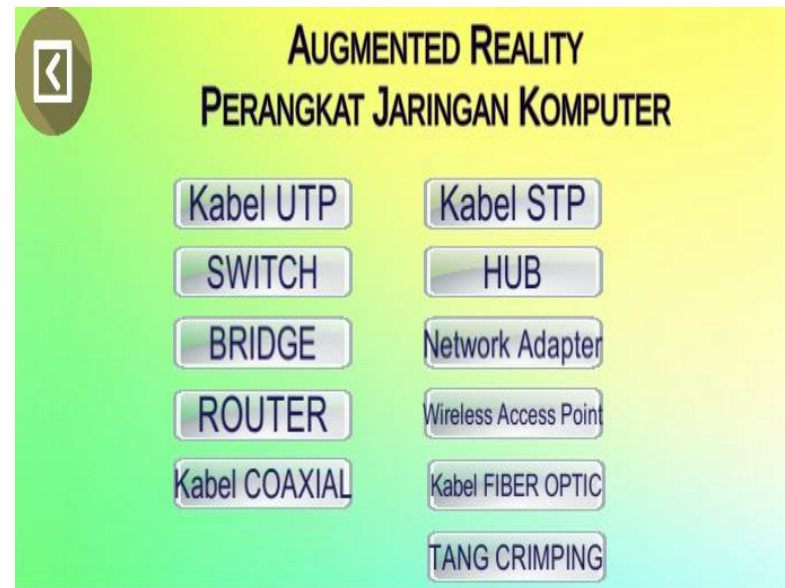

Gambar 3.Halaman MenuAR

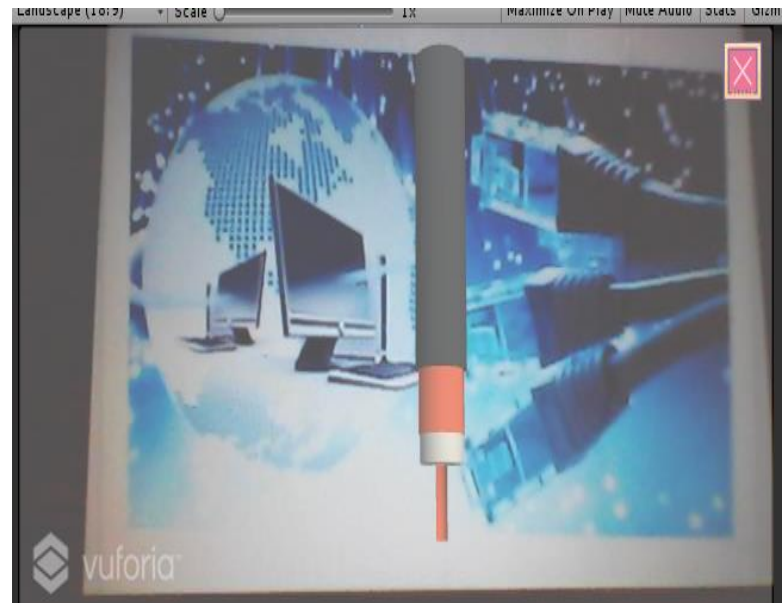

Gambar 4. Hasil Scan Marker AR

\section{Halaman Kompetensi Dasar}

Halaman Kompetensi Inti/kompetensi Dasar pada button $\mathrm{ki} / \mathrm{kd}$ berisikan indikator pencapaian dari mata pelajaran, dan berfokus pada indikator perangkat jaringan komputer.

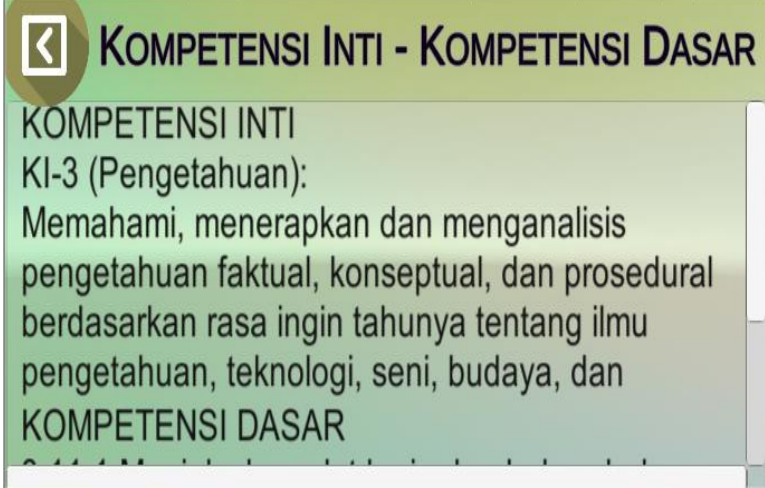

Gambar 5. Halaman KI/KD

\section{Halaman Kuis}

Halaman kuis dapat diakses peserta didik untuk evaluasi pembelajaran, berupa pertanyaan objektif yang mana perserta didik dapat memilih optional pilihan jawaban yang sudah disediakan.

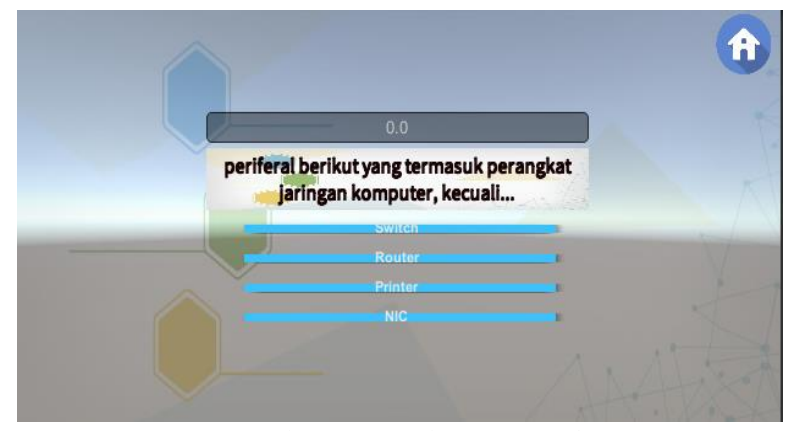

Gambar 6. Halaman Kuis

\section{Halaman Panduan}

Halaman panduan berisikan cara penggunaan media pembelajaran perangkat jaringan computeraugmented reality jika dalam menggunakan media pengguna mengalami kebingunan atau keraguan serta terdapat tombol download/unduh marker yang nanti berguna untuk mendeteksi gambar agar objek 3D muncul.

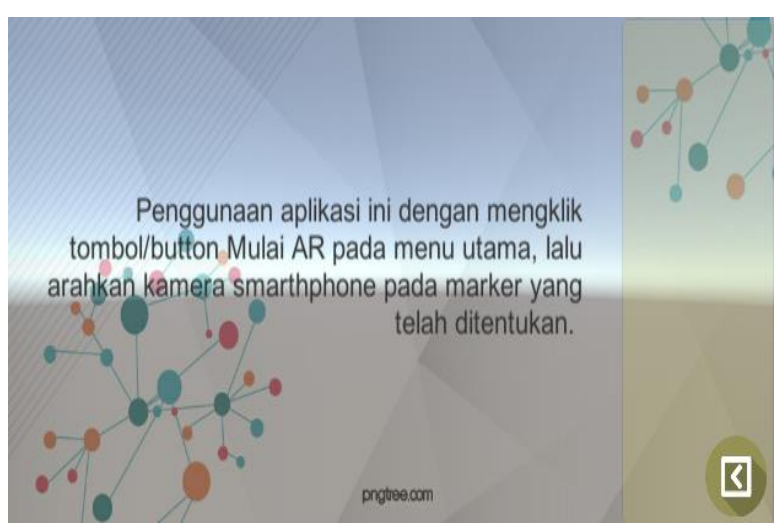

Gambar 7. Halaman Panduan 
Setelah dilakukan pengembangan media pembelajaran, terlebih dahulu Validasi media pembelajaran augmented reality diperoleh dari tanggapan validator. Validator terdiri dari dua validator media, dan dua validator materi. Nilai dari validator dapat dilihat pada tabel 2 .

Tabel 2. Penilaian Validator Media

\begin{tabular}{|c|c|c|c|}
\hline No & Indikator & Aiken's V & Kategori \\
\hline 1 & Navigasi (Tombol) & 0,81 & Valid \\
2 & Kemudahan & 0,88 & Valid \\
3 & Tulisan & 0,78 & Valid \\
4 & Tampilan & 0,84 & Valid \\
& Rata-rata & 0,83 & Valid \\
\hline
\end{tabular}

Pada tabel 2 dapat dilihat dari empat indicator yang divalidasi menghasilkan nilai Aiken's V sebesar 0,83 dan berkategori valid. Dari indicator navigasi memperoleh nilai Aiken's V 0,81, indicator kemudahan 0,88 , dan 0,78 pada indicator tulisan serta indicator tampilan dengan aiken's $\mathrm{V}$ 0,84 , keempat indicator ini masuk dalam kategori valid. Sejalan dengan validator media, hasil dari validator materi dipaparkan pada tabel 3 .

Tabel 3. Penilaian Validator Materi

\begin{tabular}{|c|c|c|c|}
\hline No & Indikator & Aiken's V & Kategori \\
\hline 1 & Pembelajaran & 0,92 & Valid \\
2 & Materi & 0,86 & Valid \\
& Rata-rata & 0,89 & Valid \\
\hline
\end{tabular}

Dari tabel 3 terlihat materi yang disajikan setelah di validasi berkategori valid dengan nilai untuk validator Materi sebesar 0,89. Dengan pencapaian nilai sebesar 0,92 pada indicator pembelajaran dan 0,86 pada indicator materi.

Selanjutnya ujicoba praktikalitas kepada guru dan siswa untuk melihat kemudahan media. Keefektifan media dari dilihat dari kemampuan siswa dalam mempemudah siswa memahami materi pembelajaran berikut hasil pengujian kemudahan media pembelajaran.

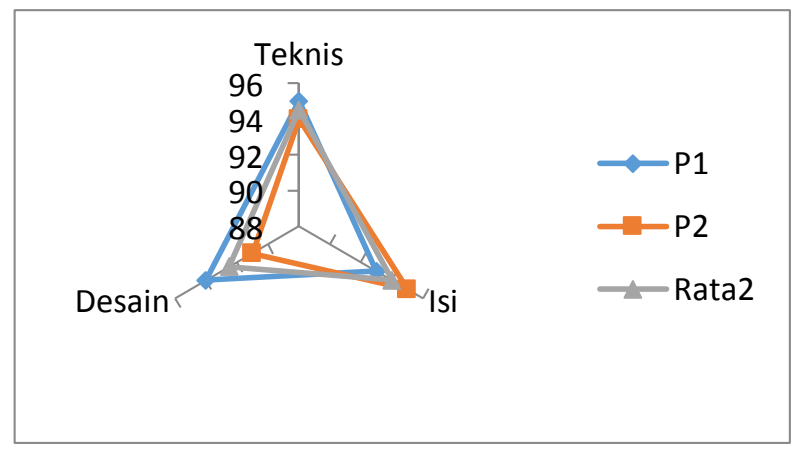

Gambar 8. Grafik Praktikalitas Respon Guru

Pada gambar 8 nampak Penilaian terhadap kepraktisanmedia pembelajaran augmented reality oleh guru yang diperoleh melalui angket. Praktisi pertama menilai media pembelajaran augmented reality yang dikembangkan tersebut mendapatkan persentase $87,00 \%$ dan berada pada kategori sangat praktis, sementara nilai praktisi kedua memberikan penilaian sangat praktis dengan persentase rata-rata 93,00\%.

Media pembelajaran augmented reality juga dinilai berdasarkan tanggapan siswa melalui angket dan hasil diketahui pada aspek kemudahan media pembelajaran augmented reality diperoleh seperti table berikut:

Tabel 4. Praktikalitas Respon Siswa

\begin{tabular}{|c|c|c|c|}
\hline No & Aspek Penilaian & $\begin{array}{c}\text { Persentase } \\
\text { Penilaian }(\%)\end{array}$ & Kategori \\
\hline 1 & Kemudahan & 84,3 & Sangat praktis \\
2 & Motivasi & 84,5 & Sangat praktis \\
3 & Kemenarikan & 86,2 & Sangat praktis \\
4 & Kebermanfaatan & 88,5 & Sangat praktis \\
& Rata-rata & 85,88 & Sangat praktis \\
\hline
\end{tabular}

Dari tabel 4 nilai persentase respon siswa terhadap aspek kemudahan $84,3 \%$, aspek motivasi $84,5 \%$, dan aspek kemenarikan $86,2 \%$, aspek kebermanfaatan $88,5 \%$, dari keseluruhan aspek penilaian didapat rata-rata yaitu $85,88 \%$. Dengan perolehan ini terlihat media pembelajaran augmented reality yang dikembangkan dikategorikan sangat praktis.

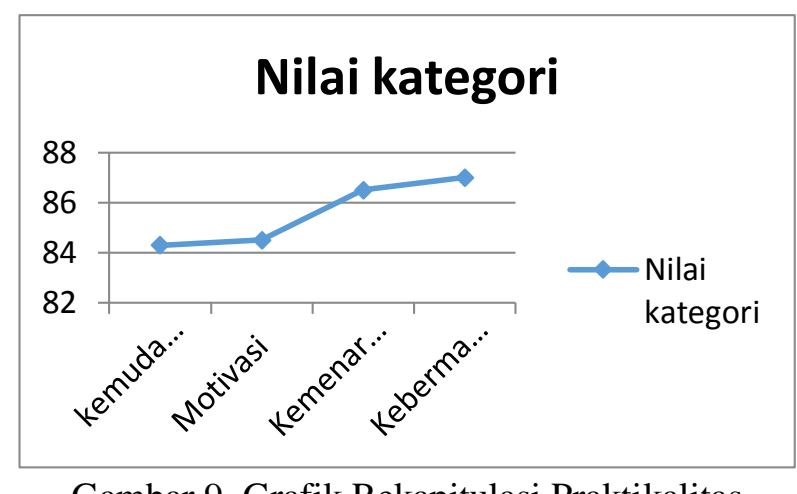

Gambar 9. Grafik Rekapitulasi Praktikalitas Berdasarkan Respon Siswa

Dari gambar 9 terlihat bahwa penggunaan media pembelajaran augmented reality perangkat jaringan komputer bagi guru dan siswa mudah dan praktis pemakaiannya. Pengguna menunjang media pembelajaran menjadikannya media yang baik atau buruk. Media mampu membuat suasana belajar menjadi menyenangkan, karena siswa lebih termotivasi untuk menyelesaikan pembelajaran untuk melihat pelajaran apa yang 
nantinya bisa dipelajari.

Keefektifan media pembelajaran augmented reality didapat dari kemampuan media membantu siswa dalam memahami materi pembelajaran. Mulyasa memaparkan keunggulan pembelajaran dengan sistem media pembelajaran augmented reality adalah berfokus pada kemampuan individual peserta didik, adanya kontrol terhadap hasil belajar melalui penggunaan standar kompetensi harus dicapai peserta didik, serta mengetahui hasil yang akan diperoleh dari dengan keterkaitan pembelajaran.

Efektifitas pengembangan media pembelajaran Augmented reality jaringan komputer didapatkan dari nilai posttest pada akhir pembelajaran. Dari Hasil uji-t didapat nilai yaitu $4,792>2,021$ dimana thitung > ttabel, dengan ini didapat perbedaan signifikan kelas eksperimen dan kelas control. Ini sejalan dengan penelitian relevan[20] yang menyimpulkan bahwa media pembelajaran sangat layak digunakan dengan hasil validasi nilai rata-rata diperoleh $92,67 \%$ dari 5 validator. Diperkuat lagi dengan hasil penelitian [21] yang menyatakan pengguanan media augmented reality dapat memenuhi kemampuan kognitif dan afektif siswa meningkat, keterampilan siswa bertambah, serta siswa lebih mudah memahami yang abstrak menjadi lebih kongkret karena adanya visualisasi augmented reality.

\section{KESIMPULAN}

Bedasarkan perancangan media pembelajaran augmented reality jaringan komputer disimpulkan bahwa Media pembelajaran augmentedreality jaringan komputer telah dikembangkan secara baik dimulai dari proses analisis kebutuhan, perancangan desain, pembuatan dan penilain terhadap pengembangan media. Dari respon guru dan siswa media pembelajaran augmentedreality jaringan komputer bersifat mudah digunakan. Pengujian kevalidan, praktikalitas dan efektifitas media pembelajaran augmented reality ini telah layak digunakan sebagai media pembelajaran. Penelitian ini bagi guru dapat dijadikan gambaran, tambahan referensi dan menjadi alternatif supaya lebih mempertimbangkan penggunaan media pembelajaran yang inovatif guna menambah pemahaman peserta didik.

\section{DAFTAR PUSTAKa}

[1] K. Vishal, "Industrial Revolution,” 2017. [Online]. Available: https://www.britannica.com/event/IndustrialRevolution.

[2] "Pengguna Smartphone di Indonesia," 2018. [Online]. Available: id.techinasia.com.

[3] N. Sudjana and A. Rivai, Media Pengajaran. Bandung: Sinar Baru Algansindo, 2013.

[4] Rusman, Pembelajaran Berbasis Teknologi Informasi dan Komunikasi. Bandung: Alfabeta, 2011.

[5] A. Arsyad, "Media Pembelajaran," Bandung: Universitas Pendidikan Indonesia, 2011.

[6] N. Jalinus and Ambiyar, Media dan Sumber Pembelajaran, 1st ed. Jakarta: Kencana, 2016.

[7] Heinich, R., Instructional Media And Technology For Learning-7th ed. New York: Pearson Education, 2005.

[8] Daryanto, Media Pembelajaran. Yogyakarta: Gava Media, 2002.

[9] M. A. Zaus and K. Krismadinata, "Suatu Kajian Literatur Masalah-Masalah yang Dihadapi dalam Mata Kuliah Jaringan Komputer," INVOTEK J. Inov. Vokasional dan Teknol., vol. 18, no. 2, pp. 1-8, 2018.

[10] J. T. Otomotif, F. Teknik, and U. N. Padang, "Pengembangan Media Pembelajaran Interaktif Pada Sistem E-Learning Universitas Negeri Padang," vol. 17, no. 2, pp. 1-10, 2017.

[11] Y. Anggraini and I. Sunaryantiningsih, "Berbasis 'Augmented Reality' pada Mahasiswa Teknik Elektro UNIPMA,” vol. 03, no. 2015, pp. 37-41, 2018.

[12] T. Khan, K. Johnston, and J. Ophoff, "The Impact of an Augmented Reality Application on Learning Motivation of Students," $A d v$. Human-Computer Interact., vol. 2019, 2019.

[13] H. S. P. Muhammad Iqbal Meslilesi, Hengky Anra, "Penerapan Augmented Reality Sebagai Media Pembelajaran Virus Dalam Mata Pelajaran Biologi Kelas X Sma (Studi Kasus : Sma Negeri 7 Pontianak)," J. Sist. dan Teknol. Inf., vol. 1, no. 2, pp. 15-19, 2017.

[14] G. Fedeli, L. \& Rossi, "A Study On Real/Virtual Relationship Through A Mobile Augmented Reality Application," Int. J. Digit. Lit. Digit. competence, vol. 5, no. 1, pp. 10-20, 2014.

[15] J. R. Vallino, "Interactive Augmented Reality," Tech. Rep. Interact. Augment. Real., no. March, pp. 1-21, 1998.

[16] M. Fernando, Membuat aplikasi android augmented reality menggunakan vuforia SDK dan Unity. Buku Online, 2013.

[17] K. Linowes, J., \& Babilinski, Augmented 
Reality for Developers. Birmingham: Packt Publishing, 2017.

[18] M. Kesim and Y. Ozarslan, "Augmented Reality in Education: Current Technologies and the Potential for Education," Procedia Soc. Behav. Sci., vol. 47, no. 222, pp. 297-302, 2012.

[19] Riduwan, Belajar Mudah Penulisan Untuk Guru-Karyawan dan Peneliti Pemula. Bandung: Alfabeta, 2010.

[20] M. Safri, S. A. Sari, and Marlina, "Pengembangan Media Belajar POP-UP Book Pada Materi Minyak Bumi," J. Pendidik. Sains Indones., vol. 05, no. 01, pp. 107-113, 2017.

[21] Mantasia and J. Hendara, "Pengembangan Teknologi Augmented Reality Sebagai Penguatan Dan Penunjang Metode Pembelajaran Di SMK Untuk Implementasi Kurikulum 2013," J. Pendidik. Vokasi, vol. 6, no. 3, pp. 281-291, 2016.

\section{Biodata Penulis}

Melsi Sari Murfi, lahir di Kepala Hilalang, 6 Juni 1993. Sarjana Pendidikan Teknik Informatika dan Komputer dari Universitas Negeri Padang, lulus tahun 2014. Mahasiswa Pendidikan Teknologi dan Kejuruan di Fakultas Teknik Program Pascasarjana UNP sejak awal tahun 2018sekarang dan bekerja paruh waktu di SMKN 1 Enam Lingkung Kabupaten Padang Pariaman Sumatera Barat.

Kasman Rukun, lahir di Batusangkar, 21 September 1955. Guru besar dalam bidang sistem informasi pada prodi pendidikan teknik informatika, dan Kepala Program Studi Doktor Pendidikan Teknologi dan Kejuruan Pasca sarja UNP sejak tahun 2019- sekarang. 